University of Nebraska - Lincoln

DigitalCommons@University of Nebraska - Lincoln

2012

Step Test Performance and Risk of Stress Fractures Among

Female Army Trainees

David N. Cowan

Walter Reed Army Institute of Research, David.Cowan@amedd.army.mil

Sheryl A. Bedno

Dwight D. Eisenhower Army Medical Center

Nadia Urban

Walter Reed Army Institute of Research

Dara S. Lee

Walter Reed Army Institute of Research

David W. Niebuhr

Walter Reed Army Institute of Research

Follow this and additional works at: https://digitalcommons.unl.edu/usarmyresearch

Cowan, David N.; Bedno, Sheryl A.; Urban, Nadia; Lee, Dara S.; and Niebuhr, David W., "Step Test

Performance and Risk of Stress Fractures Among Female Army Trainees" (2012). US Army Research. 191.

https://digitalcommons.unl.edu/usarmyresearch/191

This Article is brought to you for free and open access by the U.S. Department of Defense at DigitalCommons@University of Nebraska - Lincoln. It has been accepted for inclusion in US Army Research by an authorized administrator of DigitalCommons@University of Nebraska - Lincoln. 


\title{
Step Test Performance and Risk of Stress Fractures Among Female Army Trainees
}

\author{
David N. Cowan, PhD, MPH, Sheryl A. Bedno, MD, MPH, MS, Nadia Urban, MHS, \\ Dara S. Lee, MD, MPH, David W. Niebuhr, MD, MPH, MS
}

Background: Stress fractures and other musculoskeletal injuries are major sources of morbidity among female military trainees. Several risk factors have been postulated, particularly pre-existing fitness, usually assessed with post-entry run time for $\geq 1.0$ mile.

Purpose: Physical fitness is not formally evaluated prior to Army entry. If a valid and simple test that identified women at increased risk of stress fracture were available and could be applied prior to entry, it would facilitate cost-benefit studies of deferral or interventions. These analyses were undertaken to determine if a 5-minute step test conducted before entry identified women at increased risk.

Methods: A prospective study was conducted of weight-qualified women entering the Army in 2005-2006, with analyses completed in 2011. At the pre-entry examination, information was collected on age, BMI, smoking, race, and activity level. Everyone took the step test. All outpatient medical encounters were captured, and stress fractures and other musculoskeletal injuries identified. Women with stress fractures and those with other musculoskeletal injuries were evaluated separately.

Results: 1568 women were included in the study; 109 developed stress fractures and 803 other musculoskeletal injury. Women who failed the step test had a $76 \%$ higher stress fracture incidence and a 35\% higher incidence of other musculoskeletal injuries. There was effect modification between age and test failure for stress fracture.

Conclusions: A step test that can be administered before military entry identifies women with increased incidence of stress fracture and other musculoskeletal injury. This test could be used pre-entry to defer or target high-risk recruits for tailored fitness training before or after military entrance.

(Am J Prev Med 2012;42(6):620 - 624) @ 2012 American Journal of Preventive Medicine

\section{Introduction}

$\mathrm{O}$ veruse musculoskeletal injuries, which involve repetitive submaximal loading of musculoskeletal tissues, resulting in changes due to fatigue of tendons or inflammation of surrounding tissues, ${ }^{1}$ are an important source of morbidity among military trainees. $^{2-6}$ Military women have higher musculoskeletal injury and stress fracture risk. ${ }^{7-18}$ Risk factors for musculoskeletal injury and stress fracture among military trainees are similar. Less-fit individuals often have higher

From the Department of Epidemiology (Cowan, Urban, Lee, Niebuhr), Preventive Medicine Branch, Walter Reed Army Institute of Research, Silver Spring, Allied Technology Group (Cowan, Urban), Rockville, Maryland; and Occupational Health Service (Bedno), Dwight D. Eisenhower Army Medical Center, Fort Gordon, Georgia

Address correspondence to: David N. Cowan, PhD, MPH, Walter Reed Army Institute of Research, Preventive Medicine Branch, 503 Robert Grant Avenue, Silver Spring MD 20910. E-mail: David.Cowan@amedd.army.mil. 0749-3797/\$36.00

doi: 10.1016/j.amepre.2012.02.014 risk. ${ }^{4,6,12,17-25}$ Being overweight or underweight, ${ }^{12,22,26,27}$ older, ${ }^{5,13,22-25,28}$ sedentary lifestyle or activity leve$1 s,{ }^{4-6,13,18,27,29}$ smoking, ${ }^{5,13,18,23,25,30}$ and race $^{25}$ have been identified as risk factors.

In the Army, fitness is not evaluated until recruits reach their initial training station. Pre-accession physical activity is not assessed. The current paper on women meeting age-specific weight-for-height or body fat standards evaluates how step test performance predicts stress fracture and other musculoskeletal injury, while assessing age, race, $\mathrm{BMI}$, and smoking.

\section{Methods}

\section{Study Design and Population}

In 2004, U.S. Army Accessions Command directed that all Army applicants at six Military Entrance Processing Stations (MEPS) take a physical fitness test including a minimum number of pushups and a 5-minute step test. Those who were over body fat standards $(\mathrm{OBF})$ could enter if they passed the fitness test; among body 
fat-qualified applicants, test results were irrelevant. The Assessment of Recruit Motivation and Strength (ARMS) study, which was approved by the Walter Reed Army Institute of Research IRB, was subsequently implemented at these MEPS between February 2005 and September 2006.

The data presented here were analyzed in 2011. Only those aged $\geq 18$ years providing written informed consent for outcome follow-up were included and followed for 180 days after entry. Data sources have been previously described. ${ }^{2,31-33}$ Because only OBF women who passed the step test were included in the ARMS study, they were excluded from these analyses.

\section{Independent Variables}

Only the step test portion of the physical fitness test has been associated with injury. ${ }^{34}$ The test, modified from the Harvard Step Test, ${ }^{35-37}$ was conducted during the pre-entry physical examination. Passing the test required completing all 5 minutes at a cadence of 30 up-and-down step cycles per minute.

Other covariates recorded included race, BMI, smoking status, and age. Because of the few numbers of obese women, they were combined with overweight. Analyses were conducted on a subset of individuals on whom American College of Sports Medicine (ACSM) activity standards for adults self-reported data were collected. $^{38}$

\section{Outcome Variables}

Stress fractures were identified, and analyzed separately, regardless of the presence of other musculoskeletal injuries. Stress fracture cases were defined using a diagnostic algorithm ${ }^{6}$ applied to outpatient encounter records from military healthcare facilities. Stress fracture case definition required at least two encounters with the same diagnosis, using ICD-9 codes 733.93 (tibia or fibula); 733.94 (metatarsals); and 733.95 (other bone). The first diagnosis must have occurred $\leq 180$ days post-entry, and the second $\geq 14$ days but $\leq 180$ days after the first. If only one stress fracture code was encountered within these parameters, or if two different codes were reported, the diagnosis was considered equivocal stress fracture. These women were excluded from the denominator for the analyses of stress fracture and other musculoskeletal injury.

Musculoskeletal injuries were defined as non-stress fracture musculoskeletal injuries among women who had neither stress fracture nor equivocal stress fracture, based on the first outpatient medical encounter with ICD-9 codes 715-717, 719, 720, 724, 726728 , or $843-847$. Specific conditions included pain, sprain/strain, arthropathy, fasciitis, enthesopathy, bursitis, and, tendonosis/tendonitis. Injury sites included ankle/foot, lower leg, lumbar and sacrum/coccyx regions of the back, knee, and hip/thigh/pelvis.

\section{Statistical Methods and Data Analysis}

Frequency data were captured for all injuries. Poisson regression was used to examine the relationship between predictors and endpoints, adjusting for all factors under consideration. The adjusted incidence rate ratio (IRR) was the measure of association, with significance determined by the $95 \%$ CI. Poisson regression models with interaction terms for age group and step test results were created to examine effect modification between the two variables.
Table 1. Characteristics of body fat-qualified female ARMS study participants

\begin{tabular}{|c|c|c|c|}
\hline Characteristics & $\begin{array}{c}\text { Failed } \\
\text { step test } \\
n^{\mathrm{a}}(\%)\end{array}$ & $\begin{array}{c}\text { Passed } \\
\text { step test } \\
n^{\mathrm{a}}(\%)\end{array}$ & $p$-value \\
\hline Total & $520(33.2)$ & $1048(66.8)$ & \\
\hline \multicolumn{4}{|l|}{ Age (years) } \\
\hline 18-19 & $238(45.8)$ & $508(48.5)$ & 0.07 \\
\hline $20-24$ & 189 (36.3) & $399(38.1)$ & \\
\hline$\geq 25$ & 93 (17.9) & $141(13.5)$ & \\
\hline \multicolumn{4}{|l|}{ Race } \\
\hline White & $284(54.6)$ & $654(62.4)$ & $<0.01$ \\
\hline Black & 147 (28.3) & 232 (22.1) & \\
\hline Other & 89 (17.1) & $162(15.5)$ & \\
\hline \multicolumn{4}{|l|}{ Smoker } \\
\hline No & 415 (79.8) & $839(81.1)$ & 0.60 \\
\hline Yes & 105 (20.2) & $196(18.9)$ & \\
\hline \multicolumn{4}{|l|}{ BMI } \\
\hline $\begin{array}{l}\text { Underweight } \\
(<18.5)\end{array}$ & $28(5.4)$ & $45(4.3)$ & 0.73 \\
\hline $\begin{array}{l}\text { Normal } \\
\quad(18.5-24.9)\end{array}$ & $343(66.0)$ & $689(65.7)$ & \\
\hline $\begin{array}{l}\text { Overweight } \\
(25-29.9)\end{array}$ & $139(26.7)$ & $289(27.6)$ & \\
\hline Obese $(\geq 30)$ & $10(1.9)$ & $25(2.4)$ & \\
\hline \multicolumn{4}{|c|}{ Met ACSM adult activity standards ${ }^{\mathrm{b}}$} \\
\hline Yes & $124(57.7)$ & $208(65.0)$ & 0.09 \\
\hline No & 91 (42.3) & $112(35.0)$ & \\
\hline
\end{tabular}

${ }^{\text {aT}}$ Totals may vary across strata as some subjects were missing some data elements.

${ }^{\mathrm{b}}$ Available only for the subset of individuals who completed an ARMS activity survey ${ }^{38}$

ACSM, American College of Sports Medicine; ARMS, Assessment of Recruit Motivation and Strength

\section{Results}

Data were captured on 1568 women; their characteristics are presented in Table 1. One third of the women failed the step test. Activity data were available on 535 women. Overall, $64.2 \%$ had at least one injury (stress fracture, equivocal stress fracture, or musculoskeletal injury); $7.0 \%$ had stress fracture; $4.3 \%$ had equivocal stress fracture; and among women who had neither stress fracture nor equivocal stress fracture, $57.7 \%$ had a musculoskeletal injury. Most women (98\%) with stress fracture also had musculoskeletal injury. Poisson model results are presented in Tables 2 and 3. Step test failure was associated with stress fracture and musculoskeletal injury. Multivar- 
Table 2. Adjusted incidence rate ratios for stress fracture

\begin{tabular}{|c|c|}
\hline Stress fracture & $\begin{array}{c}\text { Adjusted incidence rate } \\
\text { ratio }(95 \% \mathrm{Cl})\end{array}$ \\
\hline \multicolumn{2}{|l|}{ Step test status } \\
\hline Pass (ref) & 1 \\
\hline Fail & $1.76(1.18,2.63)$ \\
\hline \multicolumn{2}{|l|}{ BMI } \\
\hline Underweight & $2.63(1.38,5.02)$ \\
\hline Normal (ref) & 1 \\
\hline Overweight/obese & $0.77(0.48,1.21)$ \\
\hline \multicolumn{2}{|l|}{ Age (years) } \\
\hline $18-19$ (ref) & 1 \\
\hline $20-24$ & $2.06(1.32,3.20)$ \\
\hline$\geq 25$ & $3.07(1.81,5.19)$ \\
\hline \multicolumn{2}{|l|}{ Smoker } \\
\hline No (ref) & 1 \\
\hline Yes & $1.41(0.91,2.21)$ \\
\hline \multicolumn{2}{|l|}{ Race } \\
\hline White (ref) & 1 \\
\hline Black & $0.68(0.42,1.12)$ \\
\hline Other & $0.97(0.57,1.66)$ \\
\hline \multicolumn{2}{|c|}{ Met ACSM adult activity standards } \\
\hline Yes (ref) & 1 \\
\hline No & $2.13(1.04,4.36)$ \\
\hline
\end{tabular}

Note: Values adjusted for all other variables in the model ACSM, American College of Sports Medicine

iate analysis of equivocal stress fracture (data not shown) was also conducted; associations with step test, age group, underweight BMI, and failure to meet ACSM activity standard more closely resembled stress fracture than musculoskeletal injury.

There was effect modification between age and step test results for stress fracture. The IRR for failing the test was similar for those aged $20-24$ years $(I R R=2.10)$ and those aged $\geq 25$ years (2.10); these groups were combined into a group aged $\geq 20$ years for subsequent analyses. There was no increase in the incidence of stress fracture associated with failing the test among women aged 18-19 years; among those aged $\geq 20$ years the IRR for test failure was $2.24(95 \% \mathrm{CI}=1.43,3.51)$. Among those who passed the test the IRR for $\geq 20$ was 1.77 (95\% CI $=1.07,2.92)$; among those who failed, the IRR was $3.89(95 \% \mathrm{CI}=1.81$, 8.37). Age-stratified analyses of musculoskeletal injury were conducted but the findings were not informative beyond the data in Table 3 .

\section{Discussion}

This study demonstrates that a simple step test conducted prior to military entry identifies women with higher musculoskeletal injury and stress fracture incidence. This step test also identifies men with increased musculoskeletal injury risk ${ }^{39}$ and men and women with increased attrition. ${ }^{31}$ Being underweight, aged $\geq 20$ years, smoking, and not meeting the ACSM activity standard were associated with either musculoskeletal injury or stress fracture, or both. Incidence was not higher among women aged $18-19$ years who failed; however, those aged $\geq 20$ years who failed had an incidence rate more than twice those who passed. Among those who passed, women aged $\geq 20$ years had $77 \%$ higher incidence than those aged 18-19 years;

Table 3. Adjusted incidence rate ratios for musculoskeletal injury

\begin{tabular}{|c|c|}
\hline Musculoskeletal injury & $\begin{array}{c}\text { Adjusted incidence rate } \\
\text { ratio }(95 \% \mathrm{Cl})\end{array}$ \\
\hline \multicolumn{2}{|l|}{ Step test status } \\
\hline Pass (ref) & 1 \\
\hline Fail & $1.35(1.16,1.57)$ \\
\hline \multicolumn{2}{|l|}{ BMI } \\
\hline Underweight & $1.15(0.82,1.64)$ \\
\hline Normal (ref) & 1 \\
\hline Overweight/obese & $1.03(0.88,1.20)$ \\
\hline \multicolumn{2}{|l|}{ Age (years) } \\
\hline 18-19 (ref) & 1 \\
\hline $20-24$ & $1.13(0.97,1.31)$ \\
\hline$\geq 25$ & $1.32(1.08,1.63)$ \\
\hline \multicolumn{2}{|l|}{ Smoker } \\
\hline No (ref) & 1 \\
\hline Yes & $1.21(1.02,1.44)$ \\
\hline \multicolumn{2}{|l|}{ Race } \\
\hline White (ref) & 1 \\
\hline Black & $0.84(0.71,1.00)$ \\
\hline Other & $0.93(0.76,1.13)$ \\
\hline \multicolumn{2}{|c|}{ Met ACSM adult activity standards } \\
\hline Yes (ref) & 1 \\
\hline No & $1.34(1.06,1.70)$ \\
\hline
\end{tabular}

Note: Values adjusted for all other variables in the model ACSM, American College of Sports Medicine 
among those who failed, incidence was nearly four times higher for the older group.

The step test has advantages over questionnaires and timed runs. Questionnaires, although easy to administer, are subject to over-reporting of perceived "good" responses. Run tests are time-consuming, particularly for large groups of individuals; require a substantial logistic base (track and associated personnel); and are probably not suitable for large-scale pre-accession applicant screening.

These findings have potential implications for military accession policies and practices. The use of a brief step test offers the military the option of screening all or selected categories of applicants to identify those at increased injury risk, with a potential goal of requiring that applicants who fail improve their physical fitness before entering, or to identify recruits for targeted intervention after entering. The efficacy or cost-benefit of pre-entry screening, with or without tailored fitness training, has not been determined. ${ }^{39}$ However, the identification of a simple, quick, and inexpensive pre-entry screening test provides the opportunity for addressing this issue.

These findings may also provide guidance to all women (and their trainers, coaches, and healthcare providers) who are considering beginning sports activities or entering into an occupation that requires high levels of fitness and activity. Although the step test has not been validated for civilian populations, those currently inactive or unfit, potentially defined by inability to complete the step test, should consider gradually improving fitness before entering a program where rapid increases in activity would be required. Additionally, those groups with certain other risk factors may consider modifying them, such as stopping smoking or, if underweight, attempting to increase their BMI.

The authors thank Walter Reed Army Institute of Research, Division of Preventive Medicine staff members Ms. Janice K. Gary, AAS, for her work in coordinating aspects of the ARMS study and her careful review and administrative support in preparation of the manuscripts, and Mr. Bin Yi, MS, and Ms. Xiaoshu Feng, MS, for their assistance with Poisson regression modeling. We also thank COL (ret) Margot Krauss, MD, MPH, former Chief, Department of Epidemiology, Division of Preventive Medicine, for her work in developing and implementing the ARMS study.

This study was funded by the U.S. Army Accession Command and the U.S. Army National Guard Bureau.

The views expressed are those of the authors and should not be construed to represent the positions of the Department of the Army or Department of Defense. All authors are employees of or contracted to the U.S. Army.
No financial disclosures were reported by the authors of this paper.

\section{References}

1. McGraw-Hill Concise Dictionary of Modern Medicine. New York: McGraw-Hill, 2002.

2. Cowan DN, Bedno SA, Urban N, Yi B, Niebuhr DW. Musculoskeletal injuries among overweight army trainees: incidence and health care utilization. Occup Med (Lond) 2011;61(4):247-52.

3. Cowan DN, Jones BH, Shafer R. Musculoskeletal injuries in the military training environment. In: Kelley PW, ed. Military preventive medicine: mobilization and deployment. Vol I. Washington DC: Office of the Army surgeon General and The Borden Institute, 2003. www. bordeninstitute.army.mil/published_volumes/mpmVol1/PM1ch10.pdf.

4. Jones BH, Bovee MW, Harris JM 3rd, Cowan DN. Intrinsic risk factors for exercise-related injuries among male and female army trainees. Am J Sports Med 1993;21(5):705-10.

5. Jones BH, Cowan DN, Tomlinson JP, Robinson JR, Polly DW, Frykman PN. Epidemiology of injuries associated with physical training among young men in the army. Med Sci Sports Exerc 1993; 25(2):197-203.

6. Shaffer RA, Brodine SK, Almeida SA, Williams KM, Ronaghy S. Use of simple measures of physical activity to predict stress fractures in young men undergoing a rigorous physical training program. Am J Epidemiol 1999;149(3):236- 42.

7. Lee D; Armed Forces Health Surveillance Center (AFHSC). Stress fractures, active component, U.S. Armed Forces, 2004-2010. MSMR 2011;18(5):8-11. www.afhsc.mil.

8. Strowbridge NF. Musculoskeletal injuries in female soldiers: analysis of cause and type of injury. JR Army Med Corps 2002;148(3):256-8.

9. Protzman RR, Griffis CC. Comparative stress fracture incidence in males and females in an equal training environment. Athl Training 1977;12(13):126-30.

10. Brudvig TJ, Gudger TD, Obermeyer L. Stress fractures in 295 trainees: a one-year study of incidence as related to age, sex, and race. Mil Med 1983;148(8):666-7.

11. Pester S, Smith PC. Stress fractures in the lower extremities of soldiers in basic training. Orthop Rev 1992;21(3):297-303.

12. Jones BH, Bovee MH, Knapik JJ. Associations among body composition, physical fitness, and injury in men and women Army trainees. In: Marriott BM, Grumstrup-Scott J, eds. Body composition and physical performance. Washington DC: National Academies Press, 1992: $141-73$.

13. Jones BH, Shaffer RA, Snedecor MR. Chapter 6. Injuries treated in outpatient clinics: surverys and research data. Mil Med 1999; 164(8S):1-89.

14. Deuster PA, Jones BH, Moore J. Patterns and risk factors for exerciserelated injuries in women: a military perspective. Mil Med 1997; 162(10):649-55.

15. IOM. Assessing readiness in military women: the relationship of body composition, nutrition, and health. Washington DC: National Academies Press, 1998:77-243.

16. Jones BH, Harris JMcA, Vinh TN, Rubin C. Exercise-induced stress fractures and stress reactions of bone: epidemiology, etiology, and classification. In: Pandolf KB, ed. Exercise and sport sciences reviews. Vol 17. Baltimore MD: Williams \& Wilkins, 1989.

17. Blacker SD, Wilkinson DM, Bilzon JL, Rayson MP. Risk factors for training injuries among British Army recruits. Mil Med 2008; 173(3):278-86.

18. Knapik JJ, Sharp MA, Canham-Chervak M, Hauret K, Patton JF, Jones $\mathrm{BH}$. Risk factors for training-related injuries among men and women in basic combat training. Med Sci Sports Exerc 2001;33(6):946-54. 
19. Shaffer RA, Rauh MJ, Brodine SK, Trone DW, Macera CA. Predictors of stress fracture susceptibility in young female recruits. Am J Sports Med 2006;34(1):108 -15.

20. Lappe J, Davies K, Recker R, Heaney R. Quantitative ultrasound: use in screening for susceptibility to stress fractures in female army recruits. J Bone Miner Res 2005;20(4):571-8.

21. Rauh MJ, Macera CA, Trone DW, Shaffer RA, Brodine SK. Epidemiology of stress fracture and lower-extremity overuse injury in female recruits. Med Sci Sports Exerc 2006;38(9):1571-7.

22. Heir T, Eide G. Age, body composition, aerobic fitness and health condition as risk factors for musculoskeletal injuries in conscripts. Scand J Med Sci Sports 1996;6(4):222-7.

23. Knapik JJ, Sharp MA, Canham ML, et al. Injury incidence and injury risk factors among U.S. Army basic trainees (including fitness training unit personnel, discharges, and newstarts). Aberdeen Proving Ground MD: U.S. Army Center for Health Promotion and Preventive Medicine, 1998. Epidemiological Consultation Report 1999; report no. 29-HE-8370-98.

24. Knapik J, Ang P, Reynolds K, Jones B. Physical fitness, age, and injury incidence in infantry soldiers. J Occup Med 1993;35(6):598 - 603.

25. Lappe JM, Stegman MR, Recker RR. The impact of lifestyle factors on stress fractures in female Army recruits. Osteoporos Int 2001; 12(1):35-42.

26. Finestone A, Milgrom C, Evans R, Yanovich R, Constantini N, Moran DS. Overuse injuries in female infantry recruits during low-intensity basic training. Med Sci Sports Exerc 2008;40(11S):S630-S635.

27. Ross J, Woodward A. Risk factors for injury during basic military training. Is there a social element to injury pathogenesis? J Occup Med 1994;36(10):1120-6.

28. Mattila VM, Niva M, Kiuru M, Pihlajamaki H. Risk factors for bone stress injuries: a follow-up study of 102,515 person-years. Med Sci Sports Exerc 2007;39(7):1061-6.
29. Gardner LI Jr, Dziados JE, Jones BH, et al. Prevention of lower extremity stress fractures: a controlled trial of a shock absorbent insole. Am J Public Health 1988;78(12):1563-7.

30. Munnoch K, Bridger RS. Smoking and injury in Royal Marines' training. Occup Med (Lond) 2007;57(3):214-6.

31. Niebuhr DW, Scott CT, Powers TE, et al. Assessment of recruit motivation and strength study: preaccession physical fitness assessment predicts early attrition. Mil Med 2008;173(6):555-62.

32. Niebuhr DW, Scott CT, Li Y, Bedno SA, Han W, Powers TE. Preaccession fitness and body composition as predictors of attrition in U.S. Army recruits. Mil Med 2009;174(7):695-701.

33. Bedno SA, Li Y, Han W, et al. Exertional heat illness among overweight U.S. Army recruits in basic training. Aviat Space Environ Med 2010;81(2):107-11.

34. Bedno SA, Cowan DN, Urban N, Niebuhr DW. Effect of pre-accession physical fitness on training injuries among U.S. Army recruits. Work 2012:In press.

35. Sloan AW. A modified Harvard step test for women. J Appl Physiol 1959;14:985-6.

36. Sloan AW. The Harvard step test of dynamic fitness. Triangle 1962;5:358-63.

37. Montoye HJ. The Harvard step test and work capacity. Rev Can Biol 1953;11(5):491-9.

38. Gubata, ME, Cowan DN, Bedno SA, Urban N, Niebuhr DW. Selfreported physical activity and pre-accession fitness testing in US Army applicants. Mil Med 2011;176(8):922-5.

39. Bullock SH, Jones BH, Gilchrist J, Marshall SW. Prevention of physical training-related injuries recommendations for the military and other active populations based on expedited systematic reviews. Am J Prev Med 2010;38(1S):S156-S181.

\section{Did you know? \\ When you become a member of the ACPM \\ (www.acpm.org) or APTR (www.aptrweb.org), you receive a subscription to AJPM as a member benefit.}

